\title{
Adhesion of uredospores of Phakopsora pachyrhizi on soybean seeds and their viability during storage ${ }^{1}$
}

\author{
Elisandra Batista Zambenedetti Magnani2*, Elisabeth Aparecida Furtado de \\ Mendonça $^{2}$, Maria Cristina de Figueiredo e Albuquerque ${ }^{2}$
}

\begin{abstract}
To study adhesion and viability of uredospores of the fungus Phakopsora pachyrhizi on soybean seeds during storage, suspension tests of those uredospores were carried out by washing seeds at each 30 days interval. Furthermore, germination and inoculation tests of uredospores on soybean plants were performed with uredospores collected from seeds of two soybean production areas, located in the municipalities "Chapada dos Guimarães" and "Tangará da Serra", State of Mato Grosso, Brazil. High levels of uredospores infestation were detected before storage [249.31 and 85.18 uredospores/100 seeds (U/100)] on seeds collected in both localities, respectively. After 30 days storage, these figures were 46.12 and $122.5 \mathrm{U} / 100$; at 60 days were 14.62 and $26.62 \mathrm{U} / 100$; and at 90 days were only 2.87 and 3,68 U/100, respectively; dropping to zero after 120 days storage. The percentage of germinated uredospores decreased with increasing storage periods and at 120 days germination percentage was nil. When uredospores were inoculated on soybean plants, rust symptoms were only observed for uredospores collected from freshly harvested seeds. Uredospores associated to soybean seed germinate until 90 days after storage, but are not viable after this time span. Infection of plants only occurs with inoculation of uredospores obtained from freshly harvested seeds.
\end{abstract}

Index terms: soybean rust, spores, germination, infection.

\section{Adesão de uredosporos de Phakopsora Pachyrhizi em sementes de soja e sua viabilidade durante o armazenamento}

RESUMO - Para estudar a adesão e viabilidade dos uredósporos do fungo Phakopsora pachyrhizi em sementes de soja durante o armazenamento, foram realizados testes de suspensão destes pela lavagem das sementes, a cada 30 dias, e posterior teste de germinação e inoculação em plantas, com sementes coletadas em Chapada dos Guimarães e Tangará da Serra, MT. Altos índices de uredósporos do fungo foram detectados nos lotes de sementes colhidas nas duas localidades antes do armazenamento [249,31 e 85,18 uredósporos/100 sementes (U/100)], respectivamente. Aos 30 dias de armazenamento, estes números foram de 46,12 e 122,5 U/100; aos 60 dias foram de 14,62 e 26,62 U/100; e aos 90 dias, apenas 2,87\% e 3,68 U/100, respectivamente. Aos 120 dias, a incidência foi igual a zero. O percentual de uredósporos germinados decresceu com o aumento do período de armazenamento e, aos 120 dias, a germinação também foi nula. Quando os uredósporos foram inoculados em plantas de soja, os sintomas de ferrugem apenas foram observados para aqueles uredósporos oriundos de sementes recém-colhidas. Uredósporos associados às sementes de soja germinam até 90 dias de armazenamento, mas não são mais viáveis após esse período. A infecção das plantas ocorre somente com inoculação de uredósporos obtidos de sementes recém-colhidas.

Termos para indexação: ferrugem da soja, esporos, germinação, infecção.

\footnotetext{
${ }^{1}$ Submitted on 05/28/2011. Accepted for publication on 11/17/2011.

${ }^{2}$ Departamento de Fitotecnia e Fitossanidade, UFMT, 78060-900 - Cuiabá, MT, Brasil.

*Corresponding author <elisandrazam@hotmail.com>
} 


\section{Introduction}

The fungus Phakopsora pachyrhizi Sydow \& Sydow, causal agent of the Asian Soybean Rust, as the majority of causal agents of rusts on plants, is not seed transmitted since it is an obligate biotrophic organism and grows only on living organisms with metabolic full development. Once there are no scientific reports on transmission of this pathogen via seeds, likewise there are not experimental works for the evaluation of transmission and/or adherence of uredospores of this fungus onto seeds. Notwithstanding, there are a few reports stating that some of these spores can actually be disseminated via seeds, although not by infection, but by adhesion to their tegument and/or on inert debris present in the seed sample.

According to Hershman (2004) it is possible that the Asian Soybean Rust can be transported to production fields in USA via soybean seeds, industrial soybean grains or soybean meal. With this statement, the author highlights the need of develop further studies for meticulously confirm or not such hypothesis. Bradley (2005) stated that the etiological agent of soybean rust is not disseminated via seeds and does not survive on their surfaces, but did not discard the possibility that spores might remain viable in tissues parts of pods and leaves mixed to seeds. In addition, the discover of uredospores of $P$. pachyrhizi attached to the tegument of soybean seeds from lots of seeds produced in the State of Mato Grosso, has raised the hypothesis that seeds produced in seed production areas infested with the Asian soybean Rust are able to convey viable spores from one crop season to the next.

This research work aimed at studying adherence and viability of uredospores of the fungus Phakopsora pachyrhizi on soybean seeds before and during storage.

\section{Material and Methods}

Seed samples were collected in the 2008/2009 crop season, in State of Mato Grosso, within two seed production areas that had been infected by the causal agent of the Asian Soybean Rust during the crop cycle; one in the city of "Tangará da Serra" and the other in "Chapada dos Guimarães". After harvest, seed were brought to the Seed Laboratory of the College of Agronomy and Veterinary Medicine of Federal University of Mato Grosso, without undergoing any cleaning procedure, where the assessments were performed.

In the laboratory, samples were packaged into paper bags and remained in storage on top of a laboratory bench during 120 days, under an environment with $26 \pm 2{ }^{\circ} \mathrm{C}$ average temperature and relative humidity varying from $50 \%$ to $60 \%$. The seeds were stored this manner in order to undergo environmental conditions similar to those of storage facilities, where they normally remain until the moment of being brought to field for sowing. Tests for uredospores quantification, germination, viability, and disease transmission were performed when the samples arrived in the laboratory and at each 30 days interval, during a four months storage period.

A completely randomized experimental design, with five treatments $(0,30,60,90$, and 120 days of storage), with four replications each, was used.

Uredospores quantification: before starting the test, the homogenization of samples was performed and then four subsamples of 100 seeds each (replications) were subjected to the washing suspension test, adapted from Pathak et al. (1978). To perform such procedure, each seed subsamples was transferred into a $250 \mathrm{~mL}$ capacity Erlenmeyer flask containing $15 \mathrm{~mL}$ of sterile distilled water and then subjected to mechanical shaking using an horizontal shaker apparatus, during 10 minutes.

The suspension so obtained was centrifuged at 2,500 rpm, for 10 minutes. After discharging the supernatant liquid, to each centrifuge tube $2.0 \mathrm{~mL}$ of sterile distilled water $+10 \mu \mathrm{L}$ TWEEN 20 (25\% solution) were added, and the tubes were then manually shaken. Immediately after, $15 \mu \mathrm{L}$ of suspension were removed with a pipette from each replication and transferred to microscope slides, overlaid with coverslips, and assessed for quantification and subsequent computation of occurrence index of uredospores/100 seeds.

Uredospores germination: for the test of uredospores germination, $50 \mu \mathrm{L}$ of the solution remaining from the washing suspension test were collected with a pipette; poured into a $9 \mathrm{~cm}$ in diameter Petri dish containing 2\% water/agar medium, and then aseptically distributed on the surface of the culture medium using a Drigalsky loop. The Petri dishes were afterwards placed into a BOD type chamber, at $23{ }^{\circ} \mathrm{C}$, in the dark, for a $6 \mathrm{~h}$ incubation period. After incubation, the percentage of germinated uredospores was assessed with the aid of an optical microscope, under magnification. Uredospores were computed as germinated when the length of germinative tube had two times the size of the uredospores. Each replication was composed of a single Petri dish, subdivided into four sectors. Fifty uredospores were observed per sector, thus totaling 200 uredospores per Petri dish. 
Uredospores viability: to evaluate longevity of uredospores associated to soybean seeds, periodical assessments were performed on four soybean genotypes (Pintado, RBS Valiosa, P98Y11, and PI459025) before and in all periods in which tests of washing suspension and uredospores germination were carried out.

For inoculation was performed on plants in each of the storage periods $(0,30,60,90$ and 120 days) were used $10 \mathrm{~mL}$ of the uredospores suspension from the tests of quantification and seed washing, in a concentration of $3 \times 10^{4}$ uredospores $/ \mathrm{mL}$, manual sprayed on leaves of soybean sixteen plants grown into pots under greenhouse environmental conditions. Assessments were daily performed, starting from the fifth day after inoculation, with the objective of verifying if the infection on leaves had actually occurred and also to identify the beginning of fungus sporulation. For this, samplings were performed using transparent adhesive tape, which were pressed on top of the fungus uredia and immediately after were glued to optical microscope slides. The microscope slides with adhesive tape were brought to laboratory and identification of fungal structures was performed with the aid of a to verify if uredospores had been already formed or not.

After identification of uredospores presence, at each seven days interval, assessments of incidence and diseases severity were carried out, thus totaling five evaluations starting from the sixth day after inoculation. For incidence, all leaves of the plant were assessed, considering the ratio between numbers of infected leaves per total number of leaves on the plant. For diseases severity, the scaled of grades proposed by Godoy et al. (2006) was used. Assessments were performed in the median plant portion, in two previously determinate trifoliate leaves, and only the central leaflet was used for assessment. To better visualization of disease progress and disease severity along time, disease progression curves were graphically plotted.

Data analyses were performed using the SISVAR program (Ferreira, 2008), and mean of treatments were compared by the Tukey test, at $5 \%$ probability.

\section{Results and Discussion}

Uredospores quantification: before storage, it was found 85.18 and 294.31 uredospores/100 seeds (U/100) in the seed samples collected in Tangará da Serra and Chapada dos Guimarães, respectively (Table 1).
Table 1. Mean number of uredospores of the fungus Phakopsora pachyrhizi adhered to soybean seeds present in seed samples collected in two areas infected by the causal agent of the Asian Soybean Rust, located in two different locations, and assessed before and after different storage periods.

\begin{tabular}{ccc}
\hline $\begin{array}{c}\text { Storage } \\
\text { (days) }\end{array}$ & Tangará da Serra & $\begin{array}{c}\text { Chapada dos } \\
\text { Guimarães }\end{array}$ \\
\hline Zero & $85.18 \mathrm{a}^{*}$ & $243.31 \mathrm{a}^{*}$ \\
30 & $46.12 \mathrm{~b}$ & $122.25 \mathrm{~b}$ \\
60 & $14.62 \mathrm{c}$ & $26.62 \mathrm{c}$ \\
90 & $2.87 \mathrm{~d}$ & $3.87 \mathrm{~d}$ \\
120 & $0.00 \mathrm{e}$ & $0.00 \mathrm{e}$ \\
\hline CV \% & 9.24 & 3.86 \\
\hline
\end{tabular}

* Means followed by the same letter in the columns are not statistically different among each other by the Tukey test, at $5 \%$ probability.

There has been statistically significant difference in the amount of uredospores found on seeds of samples collected immediately after harvest as well as on seeds assessed after each storage period studied for both the seed samples from Tangará da Serra or Chapada dos Guimarães (Table 1).

As it can be observed, there was a reduction of approximately $50 \%$ on the amount of uredospores adhered to seeds after 30 days storage. In the following assessments, the amount of uredospores continued decreasing, and at 120 days after storage the presence of uredospores was no more detected on the seeds (Table 1). One way of explaining this fact is that uredospores possibly wilt and dry as storage time passes, thus loosing their power of adherence, which occurs due to wrinkling they naturally have in their surfaces. Once the fungus $P$. pachyrhizi is an obligate biotrophic parasite, it needs living cells and a proper environment to survive. As the storage process occurred within an environment of low relative humidity, the dissemination structures of the pathogen did not manage to survive during that relatively long period of storage.

Uredospores germination: results on percentage of P. pachyrhizi uredospores germination during 120 days storage are presented on Table 2, where it is possible to verify that $91 \%$ and $88.68 \%$ of the uredospores present on seeds from samples collected in Tangará da Serra and Chapada dos Guimarães, respectively, were able to germinate. It is also verifiable that there was reduction on uredospores germination after three months storage and that after 120 days storage, the uredospores germination was nil. 
Table 2. Percentage of germination of uredospores of the fungus Phakopsora pachyrhizi adhered to soybean seeds present on seed samples collected in two areas infected by the causal agent of the Asian Soybean Rust, located in two different locations, and assessed before and after different storage periods.

\begin{tabular}{ccc}
\hline $\begin{array}{c}\text { Storage } \\
\text { (days) }\end{array}$ & Tangará da Serra & $\begin{array}{c}\text { Chapada } \\
\text { dos Guimarães }\end{array}$ \\
\hline Zero & $91.06 \mathrm{a}^{*}$ & $88.62 \mathrm{a}^{*}$ \\
30 & $32.06 \mathrm{~b}$ & $41.18 \mathrm{~b}$ \\
60 & $10.12 \mathrm{c}$ & $10.50 \mathrm{c}$ \\
90 & $1.93 \mathrm{~d}$ & $3.68 \mathrm{~d}$ \\
120 & $0.00 \mathrm{e}$ & $0.00 \mathrm{e}$ \\
\hline CV \% & 3.99 & 8.55 \\
\hline
\end{tabular}

* Means followed by the same letter in the columns are statistically different among each other by the Tukey test, at $5 \%$ probability.

It is likewise possible to verify that the percentage of germinated uredospores decreased with increasing of storage period of the seeds on which those fungal structures were associated. After 30 days storage, a 59\% decrease occurred on uredospores germination as compared to the same parameter assessed soon after harvest. From the second month, there has been an accentuated decrease on uredospores germination, and at 120 days there have been no uredospores germination (Table 2). Such increasing drop on germination may be explained by the fact that seeds were stored under an environment with temperature above $26{ }^{\circ} \mathrm{C}$ and relative humidity below $60 \%$.

In studies related to preservation of uredospores of this fungus species, Zambenedetti et al. (2007) found that at temperature of $-196^{\circ} \mathrm{C}$, as that of liquid nitrogen, uredospores were still able to germinate for a time span greater than 120 days, but at higher temperatures such as those of a common refrigerator $\left(4^{\circ} \mathrm{C}\right)$, a desiccator placed inside a refrigerator $\left(10{ }^{\circ} \mathrm{C}\right)$, and herborized leaves $\left(24^{\circ} \mathrm{C}\right.$ to $\left.30^{\circ} \mathrm{C}\right)$ there was a fast drop on germination capacity of uredospores.

According to Caldwell and Laing (2001), uredospores of Phakopsora pachyrhizi germinated when stored into a cold chamber at $10{ }^{\circ} \mathrm{C}$, for 120 days and survived for 50 days under room temperature.

The storage conditions in which the seeds herein studied were kept (temperature around $26^{\circ} \mathrm{C}$ and relative humidity lower than $60 \%$ ), probably have induced dormancy of uredospores or even their dehydration, hence resulting in temporary interruption on germination capacity or their death. Another important factor to be emphasized is that the pathogen is biotrophic and requires a living organism to survive and, as it does not germinate to penetrate the seed coat, thus remaining only on the its surface, it did not have the required conditions for development.

It can be likewise observed on Table 2 that under storage conditions with temperatures above $26{ }^{\circ} \mathrm{C}$, the uredospores presented sudden drop on germination at the first month and remained viable for 90 days, although with low percentage of germination, and after 120 days the germination was nil.

In seed production fields, seeds are harvested and remain stored in an environment with temperatures above $25^{\circ} \mathrm{C}$ for more than 90 days until being again brought to field for the sowing procedure. Under such conditions it is very common to find P. pachyrhizi uredospores adhered to seeds. These uredospores, however, would not represent a risk factor for the pathogen dissemination and/or for disease recrudescence, since they do not germinate after a 90 days storage period.

The rusts causing fungi are known for developing only on living hosts, but as years pass, these fungi can undergo mutations, as verified for the fungus Puccinia carthami Corda (1840), the causal agent of the Safflower Rust on plants of safflower (Carthamus tinctorius L.) (Halfon-Meiri, 1983). The same author succeeded in proving the transmission of that fungus from safflower seeds to safflower plants through teliospores, which are resistance structures that endure the most adverse environmental conditions by undergoing long dormancy periods adhered to seeds. But this is not the case observed for uredospores of Phakopsora pachyrhizi, the causal agent of Asian Soybean Rust, which remains only slightly adhered to soybean seeds; and their longevity is short (only 90 days) under environmental conditions with relative humidity lower than $60 \%$ and temperatures around $26^{\circ} \mathrm{C}$.

Uredospores viability: it was only possible to detect rust disease symptoms on plants in the experiment, when uredospores from freshly harvested seeds, i.e., before the storage, were used. The non-detection of symptoms can be explained by the fact that the pathogen is biotrophic and needs a living organism for its feeding and development. But, as uredospores were only adhered to the external surface of seed teguments, these seeds did not have conditions for providing the adequate conditions to start germination process of uredospores and consequent penetration of internal living tissues of seeds.

Once assessments and samplings on inoculated soybean plants were daily performed, it was possible to observe that the beginning of lesions occurs only eight days after 
the inoculation procedure and that for some of the assessed genotypes the presence of uredospores on the uredia formed varied among genotypes (Figures 1 and 2). For genotypes Pintado and P98Y11 the sporulation began in the ninth day after inoculation; for genotype BRS Valiosa, the sporulation occurred at the $10^{\text {th }}$ day after inoculation; and for genotype PI 459025, which has the gene Rpp4 for complete resistance, the sporulation occurred only 12 days after inoculation. These data confirm those results of Marchetti et al. (1975), Marchetti et al. (1976), Pua and Ilag (1980), Yeh et al. (1981) and Yorinori et al. (2005), who observed that maturation of uredia and beginning of uredospores production occur at the seventh day after inoculation.

By analyzing rust development on soybean plants inoculated with uredospores collected from seeds harvested in Tangará da Serra (Figure 1A) it can be seen that for genotype PI 459025 rust incidence was the lowest in all assessments performed. The genotype P98Y11 had the highest rust incidence; and at the fourth assessment, which was performed at 29 days after inoculation, the incidence was yet higher than that performed in the preceding evaluations. But at the next evaluation, increases on rust incidence percentage did not occur (Figure 1A).

Disease severity remained lower than $10 \%$ in the two first evaluations and increased starting from the third evaluation (Figure 1B) and yet had increased in the fifth evaluation. At that reproductive stage R5, however, the soybean plants had leaves starting senescence because the plant cycle was almost ending. As it can be noticed, there have been differences on disease severity among genotypes. The genotype Pintado had the highest disease severity and genotype PI 459025 the lowest disease severity (Figure 1B).
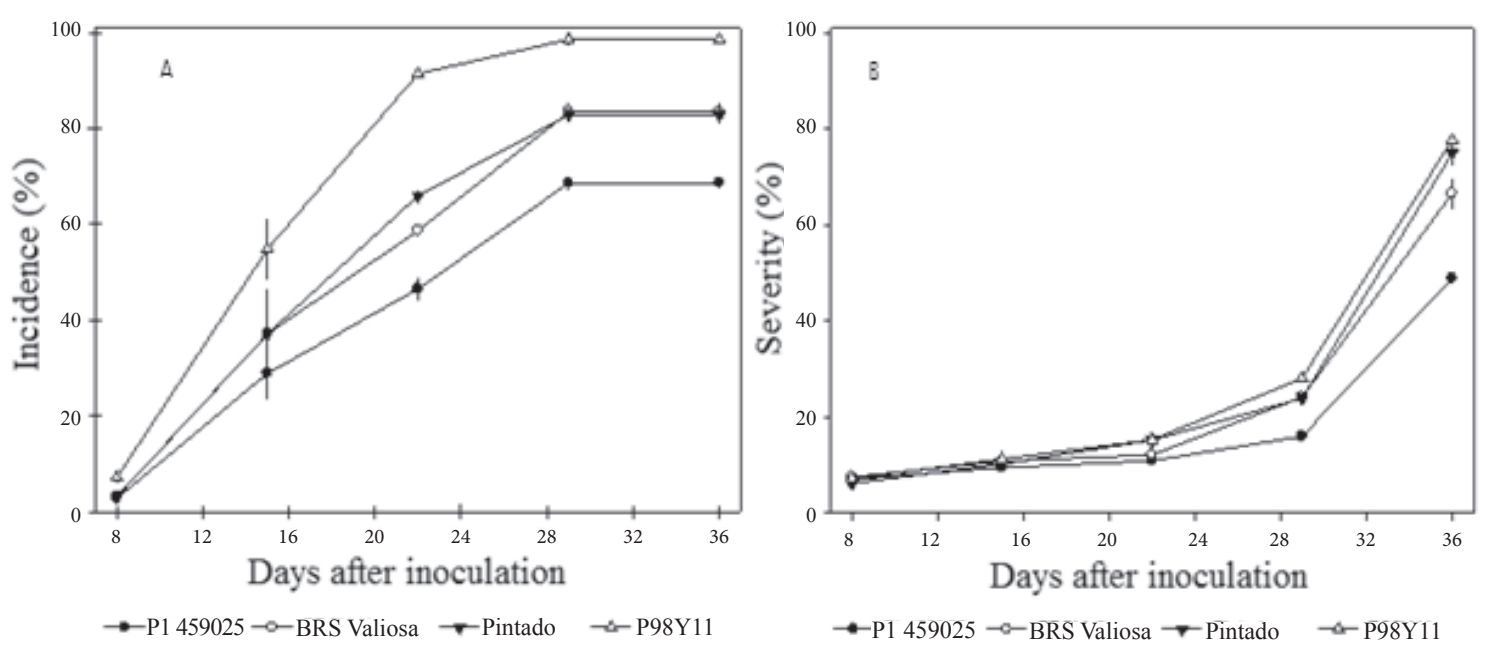

Figure 1. Progress curves of disease incidence (A) and disease severity (B) of the Asian Soybean Rust on soybean plants inoculated under greenhouse conditions with uredospores of the fungus Phakopsora pachyrhizi adhered to the seeds of seed samples freshly harvested within a rust infested area in Tangará da Serra, State of Mato Grosso.

In the second experiment, in which the soybean plants were inoculated with uredospores collected from seeds harvested in Chapada dos Guimarães, the same behavior was observed among all genotypes assessed. For incidence, the genotype 'PI 459025' had the lowest index in all the evaluations performed, and the genotypes 'P98Y111' and 'Pintado' have had the highest incidence indices (Figure 2A).

It was also verified that disease severity induced increase in the number of lesions from the first to the second assessment for all genotypes; and that after the second assessment, disease severity continued rapidly increasing on almost all genotypes, except for genotype PI 459025 that only presented statistically significant increase in the number o lesions starting from the second assessment. In the disease severity index, it was found that there have been statistically significant differences among genotypes, and that the genotype Pintado presented the highest severity index and the genotype PI 459025 presented the lowest severity index.

In this experiment it was possible to observe that uredospores, although germinating until the $90^{\text {th }}$ day after storage (Tables 1 and 2), their viability was only detected in the test performed with seeds freshly harvested, i.e., before being stored (Figures 1 and 2). 

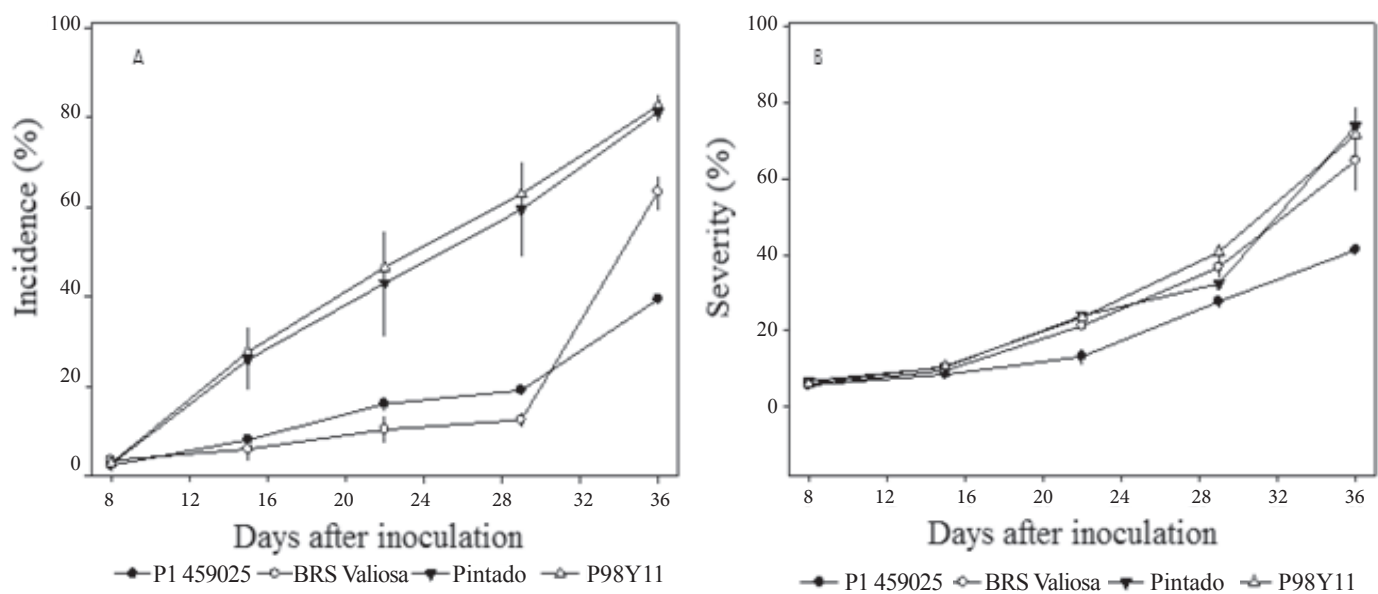

Figure 2. Progress curves of disease incidence (A) and disease severity (B) of the Asian Soybean Rust on soybean plants inoculated under greenhouse conditions with uredospores of the fungus Phakopsora pachyrhizi adhered to the seeds of seed samples freshly harvested within a rust infested area in Chapada dos Guimarães, State of Mato Grosso.

From the foregoing, it is possible to affirm that the uredospores obtained from seed lots stored for more than 90 days, although germinating, are not able to germinate and penetrate soybean plants to start the infection process. Therefore, although adhered to seeds, these uredospores probably will not cause infection on soybean plants under field conditions.

\section{Conclusions}

Uredospores of Phakopsora pachyrhizi can adhere to soybean seeds after harvest.

Uredospores of Phakopsora pachyrhizi associated to soybean seeds are able to germinate for a storage period of until 90 days, but are not able to infect soybean plants when inoculated under greenhouse conditions.

The infection of soybean plants only occurs when inoculation is carried out with uredospores associated to freshly harvested seeds.

\section{References}

BRADLEY, C.A. Recent information on fungicides for rust control in north Dakota. 2005. http://www.ndsu.edu/pubweb/ bernelso/soydiseases/ rust.shtml. www.ndsu.edu/pubweb/ bernelso/soydiseases/rust.shtml

CALDWELL, P.; LAING, M. Soybean Rust - a new disease on the move. 2001. http://www. saspp. org/content/view/20/11/Acesso em: 28 mar. 2009.

FERREIRA, D.F. SISVAR: um programa para análise e ensino de estatística. Revista Symposium, v.6, p.36-41, 2008.

GODOY, C.V.; KOGA, L.J.; CANTERI, M.G. Diagramatic scale for assessment of soybean rust severity. Fitopatologia Brasileira, v.31, n.1, p.63-68, 2006. www.scielo.br/scielo.php?script=sci_arttext.

HALFON-MEIRI, A. Seed transmission of safflower rust (Puccinia carthami) in Israel. Seed Science \& Technology, v.11, n.3, p.835-851, 1983.

HERSHMAN, D.E. Could Soybean Rust be Importe In to the U.S. with Seed, Bulk Grain, or Meal. Kentucky. Pest News, 2004.

MARCHETTI, M. A.; UECKER, F. A.; BROMFIELD, K. R. Uredial developmente of Phakopsora pachyrhizi in soybean. Phytopathology, v.65, n.7, p.822-823,1975. http://www.apsnet.org/publications/phytopathology/ backissues/Documents/1975Articles/Phyto65n07_822.pdf

MARCHETTI, M. A.; MELCHING, J. S.; BROMFIELD, K. R. The effects of temperature and dew period on germination and infection by uredospores of Phakopsora pachyrhizi. Phytopathology, v. 66, n.4, p.461-463,1976.

PATHAK, V.K.; MATHUR, S.B.; NEERGAARD, P. Detection of Peronospora manshurica (Naum.) Syd. in seeds of soybean, Glycine max. EPPO Bulletin, v.8, n.1, p.21-28, 1978.

PUA, A.R.; ILAG, L.L. Ingress and pathogenic development of Phakopsora pachyrhizi Syd. In soybean. Philippine Agriculturist, v.63, n.1, p.9-14, 1980.

YEH, C.C.; TSCHANZ, A.T.; SINCLAIR, J.B. Induced teliospore formation by Phakopsora pachyrhizi on soybeans and other hosts. Phytopathology, v.71, n.10, p.1111-1112, 1981. http://www.apsnet.org/publications/ phytopathology/backissues/Documents/1981Articles/Phyto71n10_1111.pdf

YORINORI, J.T.; PAIVA, W.M.; FREDERICK, R.D.; COSTAMILAN, L.M.; BERTAGNOLLI, P.F.; HARTMAN, G.L.; GODOY, C.V.; NUNES JUNIOR, J. Epidemics of soybean rust (Phakopsora pachyrhizi) in Brazil and Paraguay from 2001 to 2003. Plant Disease, v.89, p.675-677, 2005.

ZAMBENEDETTI, E.B.; ALVES, E.; ARAÚJO, D.V. Eventos dos processos de pre-penetração, penetração e colonização de Phakopsora pachyrhizi em folíolos de soja. Fitopatologia Brasileira, v.31, n. p.156-160, 2007 http://www.scielo.br/pdf/fb/v32n2/11.pdf 